\title{
Cubic Meter
}

National Cancer Institute

\section{Source}

National Cancer Institute. Cubic Meter. NCI Thesaurus. Code C42570.

A SI unit of volume or capacity equal to the volume of a cube with edges one meter in

length. It is equal to 1,000 liters; 1,000 cubic decimeters; $10(e+6)$ cubic centimeters; 25.3

cubic feet; 6.29 barrels. 